\title{
Managing High-Elevation Sagebrush Steppe: Do Conifer Encroachment and Prescribed Fire Affect Habitat for Pygmy Rabbits?
}

\author{
Bonnie A. Woods, ${ }^{1}$ Janet L. Rachlow, ${ }^{2}$ Stephen C. Bunting, ${ }^{3}$ Timothy R. Johnson, ${ }^{4}$ and Kelly Bocking ${ }^{5}$ \\ Authors are ${ }^{1}$ Graduate Assistant and ${ }^{2}$ Associate Professor, Department of Fish and Wildlife Sciences, University of Idaho, Moscow, ID 83844, USA; \\ ${ }^{3}$ Professor, Department of Forest, Rangeland and Fire Sciences, University of Idaho, Moscow, ID 83844, USA; ${ }^{4}$ Associate Professor, Department of \\ Statistical Science, University of Idaho, Moscow, ID 83844, USA; and ${ }^{5}$ Wildlife Biologist, Bureau of Land Management, Dillon, MT 59725, USA.
}

\begin{abstract}
Both fire and conifer encroachment can markedly alter big sagebrush communities and thus habitat quality and quantity for wildlife. We investigated how conifer encroachment and spring prescribed burning affected forage and cover resources for a sagebrush specialist, the pygmy rabbit. We studied these dynamics at spring prescribed burns in southwestern Montana and eastern Idaho during the summer of 2011. Within each spring prescribed burn, we established plots that described the habitat conditions for pygmy rabbits (forage plant biomass and habitat components that influence predation risk) in areas that were burned, adjacent areas of conifer encroachment, and areas that were neither burned nor encroached. We analyzed the data for significant differences in habitat conditions between the paired reference and encroachment plots and modeled when the burned areas would approximate the conditions on the paired reference plots. Biomass of forage plants and habitat components that reduce predation risk differed between undisturbed reference plots and areas that were either burned or encroached with $>30 \%$ conifer canopy. Our models estimated that 13-27 yr were required for a spring prescribed burn to provide levels of cover and forage resources similar to sagebrush steppe reference plots. We documented that vegetation composition was associated with the plot designations (burn, reference, or conifer encroachment), but not with other abiotic factors, such as soil texture, aspect, or study site; this suggested that the documented differences in habitat were related to the treatments, rather than being sitespecific characteristics. The information from this study can contribute to habitat management plans for high-elevation mountain big sagebrush sites where conifer encroachment is altering habitat for sagebrush-dependent wildlife species.
\end{abstract}

Key Words: Brachylagus idahoensis, Douglas fir encroachment, habitat quality, mountain big sagebrush, recovery interval, spring prescribed burning

\section{INTRODUCTION}

Throughout the basins and ranges of western North America, Euro-American settlement has altered and removed sagebrush communities. Consequently, more than 350 associated plants and animals are species of conservation concern (Noss et al. 1995; Knick et al. 2003; Suring et al. 2005). The estimated historical range of sagebrush steppe was $>62$ million ha (West 1996; Miller et al. 2000; Knick et al. 2003). Now, only 56\% of that expanse remains, and the residual portions are highly fragmented (Knick et al. 2003; Schroeder et al. 2004). Reduction in the extent and connectivity of sagebrush ecosystems is related to the individual and synergistic effects of grazing, agriculture, energy development, invasive species, and changing fire regimes (Knick et al. 2003; Davies et al. 2011).

Fire is a major disturbance and driver of transition among successional states in sagebrush steppe. Historically, at low elevations where basin big sagebrush (Artemisia tridentata

\footnotetext{
Research was funded by the University of Idaho, Bureau of Land Management, US Forest Service, Idaho Dept of Fish and Game, Bureau of Reclamation, and Zoo Boise Conservation Fund.

Correspondence: Bonnie A. Woods, Dept of Fish and Wildlife Sciences, University of Idaho, Moscow, ID 83844, USA. Email: wood4721@vandals.uidaho.edu Current address: Bonnie A. Woods, 6679 E Chiricahua Dr, Pearce, AZ 85625, USA.
}

Manuscript received 3 October 2012; manuscript accepted 10 April 2013.

(c) 2013 The Society for Range Management
Nutt. subsp. tridentata) and Wyoming big sagebrush (Artemisia tridentata Nutt. subsp. wyomingensis Beetle \& Young) were prevalent, presettlement fires were infrequent (mean fire return intervals were $50 \mathrm{yr}$ to several hundred years; Knick et al. 2005). In modern times, fire frequency has increased because of anthropogenic ignition sources and invasion by fire-promoting nonnative plant species, such as cheatgrass (Bromus tectorum L.; Davies et al. 2011). Consequently, sagebrush steppe is being replaced by invasive annuals (Brooks et al. 2004; Knick et al. 2005). At higher elevations (>1600 m), along the borders of coniferous forests, mountain big sagebrush (Artemisia tridentata Nutt. subsp. vaseyana [Rydb.] Beetle) communities also are being altered by changing fire regimes, but it is the cessation of fire causing the changes. In mountain big sagebrush steppe, fires were historically more frequent (estimates of mean fire return intervals ranged from $15 \mathrm{yr}$ to $40 \mathrm{yr}$; Harniss and Murray 1973; Houston 1973; Burkhardt and Tisdale 1976; Arno and Gruell 1983; Miller and Rose 1999; Knick et al. 2005). Currently, the reduction of fine fuels through cattle grazing and active fire suppression have reduced the frequency of fire on the landscape. Additionally, increased concentrations of atmospheric $\mathrm{CO}_{2}$ could stimulate growth in coniferous species (Knapp and Soule 1996; Miller and Tausch 2001; Knapp and Soule 2008; but see Miller and Rose 1999). The resulting effect is that conifers are expanding and infilling in mountain big sagebrush steppe habitats (Burkhardt and Tisdale 1976; Arno and Gruell 1983; Miller and Rose 1999; Knick et al. 2003). 
Changes to disturbance regimes could affect wildlife using sagebrush for seasonal forage and sagebrush obligates that rely on the sagebrush steppe for all of their habitat needs (Wambolt et al. 2001; Knick et al. 2005; Beck et al. 2009; Davies et al. 2011). In Montana and Idaho, mountain big sagebrush steppe covers millions of hectares and provides important habitat resources for a diversity of wildlife species (Arno and Gruell 1983). Conifer encroachment changes plant communities by decreasing light infiltration, increasing litter accumulation, and changing the biological, chemical, and hydrological characteristics of soils (Haugo and Halpern 2007). Conifer encroachment can be detrimental to sagebrush-associated wildlife because of the loss of the sagebrush understory, fragmentation of habitat, reduction in herbaceous forage, and decrease in structural complexity near the ground, which could increase predation risk (Commons et al. 1999; Knick et al. 2005; Miller et al. 2005). Furthermore, increasing levels of conifer encroachment can decrease fine fuels and, consequently, alter the fire regime. The likelihood of low to moderate severity surface fires, which remove conifers, is reduced. When fires do occur, they result in canopy fires that burn with high severity (Arno and Gruell 1983; Tausch 1999; Knick et al. 2005).

A common method for removing encroaching conifers from sagebrush steppe is prescribed burning. Use of prescribed burns is relatively inexpensive and often more effective than mechanical treatment at controlling dense conifer growth and removing small conifer seedlings (Miller et al. 2005; Davies et al. 2011). Prescribed burns typically are conducted during the spring or fall when many plants are dormant and fuel potential for a severe fire is decreased (Bunting et al. 1987; Lesica et al. 2007). However, big sagebrush is sensitive to fire, demonstrating $100 \%$ mortality and complete stand replacement after burning (West 2000; Davies et al. 2011). In addition, big sagebrush cannot resprout from the root crown after a fire; therefore, recruitment of sagebrush is reliant on wind dispersal of seeds from adjacent seed sources, and composition of the soil seed bank (West 2000; Allen et al. 2008; Ziegenhagen and Miller 2009). Consequently, recovery can be extremely variable. Fire can increase nutrient cycling and the production of grasses and forbs in the first few years, but evidence for longterm trends is lacking (Harniss and Murray 1973; Beck et al. 2009; Rhodes et al. 2010; Bates et al. 2011; Miller et al. 2013). Response of vegetation to fire also can be influenced by topography, climate, fuel load, fire severity, and soil properties (Johnson and Payne 1968; Winward 1985; Miller et al. 2013). The time frame and composition of plant recruitment in a burned area affects the forage and cover resources available for wildlife.

The pygmy rabbit (Brachylagus idaboensis Merriam 1891) is the smallest rabbit in North America, and it relies exclusively on sagebrush habitats for forage and protection from predators (Green and Flinders 1980; Gabler et al. 2001; Thines et al. 2004). Predation by a diverse community of both aerial and terrestrial predators is a significant cause of mortality for pygmy rabbits (Estes-Zumpf and Rachlow 2009; Crawford et al. 2010; Price et al. 2010). Connections between habitat structure and predation risk can be complex due to multiple functional habitat components, including concealment and visibility, which influence predation risk both independently and synergistically (Lima and Dill 1990; Camp et al. 2012,
2013). Animals can reduce predation risk by using cover that provides concealment; however, that same cover also can obstruct visibility of the surrounding area, a habitat component that facilitates detection and influences perception of approaching predators (Lima and Dill 1990; Embar et al. 2011). Visibility, which allows for the early detection of predators, is potentially important when pygmy rabbits are foraging (Woods 2012), whereas concealment is favored for the reduction in predation risk (actual or perceived) when rabbits are disturbed by a predator (Camp et al. 2012). Understanding how conifer encroachment and spring prescribed burning influence both visibility and concealment in the sagebrush steppe is necessary to evaluate the potential impact of habitat alteration on risk of predation for pygmy rabbits.

Pygmy rabbits rely on big sagebrush steppe vegetation for forage. Their diet consists of $99 \%$ sagebrush during the winter, with the addition of grasses (up to $50 \%$ diet composition) and forbs (up to $30 \%$ diet composition) during the summer (Green and Flinders 1980; Thines et al. 2004). Pygmy rabbits tend to use relatively small areas, especially during winter when they forage primarily on sagebrush (Sanchez and Rachlow 2008). Disturbance, such as conifer encroachment and prescribed burning, could have significant effects on forage resources for pygmy rabbits.

This study examined how conifer encroachment and spring prescribed burns changed concealment, visibility, and the biomass of forage plants for pygmy rabbits. We predicted that both conifer encroachment and prescribed burns would significantly alter these habitat resources. We expected that these effects would increase with increasing levels of conifer encroachment and decrease with time after a prescribed burn. We measured habitat characteristics in burned, encroached (phases I-III, Miller et al. 2005), and reference plots at historic spring burns ranging in age from $6 \mathrm{yr}$ to $32 \mathrm{yr}$ old, and we modeled change in the sagebrush habitat over time. We assessed the fit of patterns of community composition to our disturbance-oriented plot designations and abiotic factors (soil texture, aspect, and study site). Our goal was to provide information about spring prescribed burning and conifer encroachment in mountain big sagebrush steppe that was relevant to habitat needs for pygmy rabbits. This information can be used by land and wildlife managers to assess potential consequences of habitat modification and to design habitat restoration strategies.

\section{METHODS}

\section{Field Methods}

We conducted field work from May to August of 2011. We selected 10 historic prescribed burns conducted in the spring in Silverbow and Beaverhead counties of southwestern Montana and the adjacent Lemhi County in eastern Idaho. This region is characterized by cold winters $\left(30-\mathrm{yr}\right.$ mean: $\left.-7.1^{\circ} \mathrm{C}\right)$ and moderate summers (30-yr mean: $15.6^{\circ} \mathrm{C}$; NOAA 2012). Average annual precipitation over the past $30 \mathrm{yr}$ was 324 $\mathrm{mm}$, with approximately half of the precipitation falling between May and September (NOAA 2012).

All burns included in our sample were conducted during the spring to control conifer encroachment in mountain big 
sagebrush steppe within the range of the pygmy rabbit. We focused on spring burns because they are documented to be less severe than fall burns and more likely to create a mosaic structure of burned and unburned patches; therefore spring burns are suggested for use in sagebrush-grass lands to avoid or reduce negative implications for wildlife (Bunting et al. 1987; Bates et al. 2006).The number of years since the prescribed burn treatment ranged from $6 \mathrm{yr}$ to $32 \mathrm{yr}$. We used ArcGIS 10 to map and randomly place five plots within each study site (Beyer 2004; ESRI 2011). We placed one plot within the burn perimeter obtained from the original burn unit maps provided by the US Forest Service and the Bureau of Land Management. We placed a reference plot in adjacent unburned sagebrush steppe without conifer encroachment. Reference plots were not pretreatment controls, but instead served as a proxy for what the burn plot might be like if it had not burned. These plots allowed us to account for site-level variation and use historic burns to provide a greater span of time for inference (Lesica et al. 2007). At each site, we also placed three plots within progressively denser levels (phases I-III) of conifer encroachment. We used National Agriculture Imagery Project data (1-m resolution) to delineate encroachment phases described by Miller et al. (2005). In phase I encroachment $(<10 \%$ conifer canopy cover), shrubs were a dominant influence on ecosystem processes. In phase II encroachment, canopy cover of conifers ranged from $10 \%$ to $30 \%$, and shrubs and conifers were assumed to have equal influence on the ecological processes of a site. Phase III encroachment indicated a closed conifer canopy with $\geq 30 \%$ cover, and the encroaching conifers were the primary layer influencing the area (Miller et al. 2005). The most prevalent conifer at our sites was Douglas fir (Pseudotsuga menziesii [Mirb.] Franco). Rocky Mountain juniper (Juniperus scopulorum Sarg.) and lodgepole pine (Pinus contorta Douglas ex Loudon) occurred occasionally within our study sites.

To minimize the influence of other sources of disturbance/ influence, the five plots established at each site were randomly placed within areas of similar aspect, slope, and ecological site/ soil type, within $200 \mathrm{~m}$ of elevation difference, without obvious topographic irregularities (e.g., water catchments or rock extrusions), $>50 \mathrm{~m}$ away from a developed road or fence, within the same pasture and $\geq 200 \mathrm{~m}$ away from the nearest cattle tank. Ecological sites between plots within a study site were matched as closely as possible using the known ecological site of the dominant soil unit (two study sites=droughty steep ecological site, one study site $=$ droughty ecological site, one study site=loamy ecological site, one study site=loamy steep ecological site, and one study site $=$ four plots that were a loamy ecological site, one plot that was a loamy steep ecological site with a similar slope to the loamy plots; USDA-NRCS 2011). Where ecological site data were not available (four study sites), plots were matched on the same soil map units with comparable aspects and slopes to approximate an ecological site. We assessed abiotic factors for each plot, including aspect, slope, elevation, and soil texture. We measured aspect (facing downhill) and elevation of the plot using a handheld global positioning system. At the middle of each transect, we determined soil texture by hand to a depth of $13 \mathrm{~cm}$ (Thien 1979). Most plots (47 out of 50) had the same soil textures for all four transects. In three plots, we assigned plot soil texture using the dominant value (occurrence on three out of four transects). The predominant soil texture was clay-loam, with clay-silt occurring occasionally, and sand-silt or sand-loam occurring rarely.

Measurements were conducted before cattle-grazing occurred that year. Cattle-grazing on federal lands, in this area of Montana and Idaho, is generally on a rest/rotation schedule with grazing occurring for 15-30 d, followed by a full year of rest every third or fourth year. Average stocking rates are 2-4 ha $\cdot \mathrm{AUM}^{-1}$. Typically, a prescribed burned area is rested postfire for two seasons (R. Martin and K. Schmidt, personal communication. February 2013).

Plots were placed $>30 \mathrm{~m}$ from each other to avoid spatial autocorrelation. We visually confirmed the appropriateness of each plot in the field. Plots were $30 \times 30 \mathrm{~m}$ in dimension and were characterized by four parallel $30-\mathrm{m}$ transects placed $7.5 \mathrm{~m}$ apart with a random start.

We assessed predation risk from aerial and terrestrial predators by estimating two functional components of cover: concealment and visibility (Camp et al. 2012; Woods 2012). Measurements were collected at three points, spaced at 10-m intervals (with a random start) along each transect and $1 \mathrm{~m}$ on alternating left or right sides of each transect. We measured concealment by placing a $15 \times 15 \mathrm{~cm}$ red-and white-checkered profile board at the random point and visually determining the proportion of 25 squares that were $\geq 50 \%$ concealed from a random direction. Visibility was assessed placing a camera on a mini-tripod $8 \mathrm{~cm}$ above the ground at the random point location and taking a photograph of a $1 \times 1 \mathrm{~m}$ board in a random direction. We placed a 100-intersection grid over the photographs and counted the number of intersections in which vegetation did not obscure. This effectively sampled the $1-\mathrm{m}^{2}$ board at $10-\mathrm{cm}$ intervals. For concealment and visibility relative to terrestrial predators, we collected measurements in a random direction at distances of $4 \mathrm{~m}, 8 \mathrm{~m}$, and $12 \mathrm{~m}$ away from the random point, because intervening vegetation would likely alter these components across varying distances between the prey and predator (Camp et al. 2012; Woods 2012). For aerial concealment, we observed the profile board from a height of $1.5 \mathrm{~m}$ directly above, and for aerial visibility, we took the photograph directly upward and estimated the proportion of the view that was not obscured by vegetation.

We estimated canopy cover of shrubs and conifers using the line-intercept method with a 5-cm gap interval (Canfield 1941). We separated sagebrush and conifer cover by seedling $(<10 \mathrm{~cm}$ in height), juvenile $(>10 \mathrm{~cm}$; no flowers or cones), mature $(>10 \mathrm{~cm}$ with flowers or cones), declining ( $\geq 50 \%$ dead material), and dead life phases. We separated incidental shrub genera (e.g., rabbitbrush [Ericameria Nutt.], currant [Ribes L.], wild rose [Rosa L.], wild raspberry [Rubus L.], and snowberry [Symphoricarpos Duham.]) into live and dead life phases.

We assessed forage biomass by genera within three $0.5 \times 0.5$ $\mathrm{m}$ quadrats, spaced at $10-\mathrm{m}$ intervals (with a random start) along each transect and $1 \mathrm{~m}$ from the transect on alternating right or left sides. We clipped plots at a stubble height of $1 \mathrm{~cm}$ for estimation of biomass for grasses and forbs. Plant samples were dried for $>24 \mathrm{~h}$ at $100^{\circ} \mathrm{C}$. We determined forage genera that were relevant to pygmy rabbits using a compiled list of genera identified in microhistological analysis of fecal pellets and additional genera that were noted in the diet of pygmy 
rabbits in previous studies (Table 1; Green and Flinders 1980; Gahr 1993; Siegel 2002). For the microhistological analysis, we collected fecal pellets and created two composite samples drawn from $\geq$ six pellet groups at two sites within our study area ( $n=4$ composite samples). The microhistological samples were analyzed by the Wildlife Habitat Lab at Washington State University (Davitt and Nelson 1980). Of the 73 plant genera present in our plots, we identified 30 forage genera.

\section{Analysis Methods}

We analyzed our data for the effects of the encroachment phase and time since the prescribed burn on 19 habitat variables relevant to pygmy rabbits. Response variables were aerial and terrestrial visibility and concealment (terrestrial measures were completed at three distances), canopy cover of mature mountain big sagebrush, biomass of 30 forage genera grouped as forage grasses and forage forbs, and eight individual forb genera with $\geq 1.0 \%$ relative biomass in our study sites. Biomass per quadrat, and concealment and visibility measurements were averaged to the transect level with four transects nested within a plot. We transformed canopy cover of mature sagebrush and concealment and visibility values with an arcsine square root transformation, and we used a square root transformation for forage forb and grass biomass to meet the assumptions of normality and homoscedasticity.

The measurement for the $i$ th transect within the $j$ th plot at the $k$ th site was modeled using a multilevel mixed model (PROC NLMIXED; SAS Institute 2008)

$$
Y_{i j k}=\beta_{0 j}+\beta_{1 j} a g e_{i j k}+\gamma_{j k}+\delta_{k}+\varepsilon_{i j k},
$$

where $\beta_{0 j}$ captures the effect of plot type $(j=1,2, \ldots, 5$ correspond to burned, reference, and phases I-III, respectively), $\delta_{k}$ and $\gamma_{j k}$ are random site-specific and plot-within-site-specific effects, and $\beta_{1 j} a g e_{i j k}$ represents the effect of the age of the burn (in years) for plot $j$. Because the age of a burn is only an attribute of the burn treatment plot and not the reference or phase I-III plots, we specified a restriction on the interaction between plot and burn age by setting $\beta_{1 j}=0$ for all nonburned plots (i.e., $j>1$ ).

This model allowed us to estimate the number of years at which the expected measurement of the burn plot equaled that of the reference plot as

$$
\left(\beta_{02}-\beta_{01}\right) / \beta_{1 j}
$$

Comparisons among the reference and phase I-III plots were made using contrasts of the form $\beta_{0 j}-\beta_{0 j}$ for all $j, j>1$. All estimates were maximum likelihood estimates, and tests and confidence intervals were based on Wald statistics. We estimated the mean recovery times for habitat (i.e., the average time after a burn when specific habitat characteristics did not differ from estimates of those parameters in the reference plots). These confidence intervals for the "recovery point" of the burn, which approximates the reference plot conditions, were obtained using the delta method. To compare each phase of conifer encroachment (phases I-III) to the reference plots, we used pairwise comparisons with a Sidak adjustment for three comparisons $(\alpha=0.016)$ to control for family-wide type I error (Sidak 1967). To investigate the effect of time since the burn,
Table 1. Diet composition (\%) from the microhistological analysis of pygmy rabbit pellets collected at sites in southwestern Montana during 2010, and the total relative biomass (\%) of those plants collected from fire and conifer encroachment plots in southwestern Montana and eastern

\begin{tabular}{|c|c|c|c|}
\hline Forage genera & $\begin{array}{l}\text { Documentation } \\
\text { source }^{1}\end{array}$ & $\begin{array}{c}\text { Microhistological } \\
\text { diet composition (\%) }\end{array}$ & $\begin{array}{c}\text { Relative } \\
\text { biomass (\%) }\end{array}$ \\
\hline Artemisia tridentata Nutt. & $\mathrm{MH}, \mathrm{GF}, \mathrm{G}, \mathrm{S}$ & 70.93 & 16.00 \\
\hline Artemisia frigida Willd. & $\mathrm{MH}$ & 14.10 & 0.01 \\
\hline Forage grasses and sedges ${ }^{2}$ & $\mathrm{MH}, \mathrm{G}, \mathrm{S}, \mathrm{GF}$ & 13.90 & 46.18 \\
\hline Achillea L. & $\mathrm{GF}, \mathrm{G}$ & $-^{3}$ & 1.64 \\
\hline Antennaria Gaertn. & $\mathrm{MH}, \mathrm{GF}$ & 0.80 & 6.77 \\
\hline Arenaria L. & $\mathrm{MH}, \mathrm{GF}$ & 6.60 & 1.99 \\
\hline Astragalus L. & $\mathrm{MH}, \mathrm{GF}, \mathrm{S}$ & 0.40 & 1.40 \\
\hline Balsamorhiza Nutt. & S & - & 0.33 \\
\hline Cirsium Mill. & S & - & 0.02 \\
\hline Comandra L. & G & - & 0.01 \\
\hline Crepis L. & $S$ & - & 0.11 \\
\hline Ericameria Nutt. & $\mathrm{MH}, \mathrm{G}, \mathrm{S}, \mathrm{GF}$ & 1.00 & 0.15 \\
\hline Erigeron $\mathrm{L}$. & $S$ & - & 1.55 \\
\hline Haplopappus Cass. & $S$ & - & 0.04 \\
\hline Lithospermum L. & S & - & 0.49 \\
\hline Lomatium Lindley & S & - & 0.09 \\
\hline Lupinus L. & $\mathrm{MH}, \mathrm{GF}$ & 0.50 & 12.08 \\
\hline Orthocarpus Nutt. & S & - & 0.69 \\
\hline Penstemon Schmidel & GF,S & - & 0.82 \\
\hline Phlox L. & $\mathrm{MH}, \mathrm{S}$ & 0.50 & 3.09 \\
\hline Ribes $\mathrm{L}$. & GF & - & 0.01 \\
\hline Tetradymia DC. & S & - & 0.01 \\
\hline Tragapogon L. & S & - & 0.05 \\
\hline
\end{tabular}
Idaho in 2011.

${ }^{1} \mathrm{MH}$ indicates microhistological analysis; GF, Green and Flinders 1980; G, Gahr 1993; S, Siegel 2002.

${ }^{2}$ Forage sedges and grasses include junegrass (Koeleria cristata [Ledeb.] Schult.), Idaho fescue (Festuca idahoensis Elmer), bluebunch wheatgrass (Pseudoroegenaria spicata [Pursh] Á. Löve), sedge (Carex spp. L.), bluegrass (Poa spp. L.), needlegrass (Stipa [Achnatherum] spp. L.), and brome (Bromus spp. L.).

${ }^{3}$ Genera that have been previously documented but are not present in the microhistological analysis are represented by dashes.

we evaluated whether the slope of the variable across time was significantly different than zero $(\alpha=0.05)$.

Because environmental characteristics, such as soil, aspect, or other site-level characteristics could potentially confound interpretation of the data we collected, we used a nonmetric multidimensional scaling ordination (NMS) to visualize the fit of vegetation community composition relative to our plot designations (burn, reference, phases I-III) and the additional abiotic factors (Kruskal 1964; Peck 2010; McCune and Mefford 2011). NMS is a method that represents community composition by arranging units (for this study $N=50$ plots) in rank order of their similarities using an ecological distance measure (Clarke 1993). This ordering is completed for multiple iterations with random starting configurations to minimize the lack of fit (known as stress for this method). Final stress values should be lower than 10 to draw inferences from this method (Peck 2010). NMS is a robust technique to describe community composition despite the departures from normality and zeroinflation commonly encountered in data describing community composition (Clarke 1993). To conduct the NMS ordination, 
we used plot level averages for habitat variables, with additional vegetation measures of shrub and tree canopy cover and herbaceous biomass for all genera and life phases with $\geq 0.05 \%$ frequency across plots. We used a Bray-Curtis (Sorenson) measure for ecological distance, which provides a metric of the absolute abundance of a response variable for each unit (Winfree et al. 2007). This metric has performed well as a robust measure of ecological distance when compared with true ecological distances provided by simulated data (Faith et al. 1987). We visualized the ordination by graphing the ecological distances of the plots and overlaying convex hulls for factor groupings of plot type, site, aspect, and soil texture. This facilitated drawing inferences about the relative connection between disturbance, abiotic characteristics, and vegetative community composition.

\section{RESULTS}

\section{Conifer Encroachment}

High levels of conifer encroachment markedly influenced most of the pygmy rabbit habitat parameters measured. In comparison with reference plots, phase III plots $(>30 \%$ conifer canopy cover) showed decreases in aerial visibility $(t=4.57$, $P=0.010, \mathrm{df}=4$, adjusted $\alpha=0.016$ for results until otherwise noted; Fig. 1A), and increases in terrestrial visibility at $4 \mathrm{~m}$ $(t=-4.58, P=0.010)$ and $8 \mathrm{~m}(t=-4.24, P=0.013$; Fig. $1 \mathrm{~B})$. Phase III plots also exhibited less terrestrial concealment at $4 \mathrm{~m}$ $(t=4.91, P=0.008)$ and $8 \mathrm{~m}(t=3.33, P=0.008$; Fig. $1 \mathrm{C})$ relative to paired reference plots. These differences were not evident for aerial concealment or terrestrial concealment and visibility measured at $12 \mathrm{~m}(P>0.02)$. Plots with less conifer encroachment (phase I and II plots) did not differ from reference plots in any measures of concealment or visibility $(P>0.05)$.

High levels of conifer encroachment also reduced availability of forage plants for pygmy rabbits. Phase III plots, relative to reference plots, exhibited decreases in mature big sagebrush cover $(t=5.80, P=0.004$; Fig. 1D), biomass of forage forbs $(t=4.7, P=0.009)$, and biomass of forage grasses $(t=4.31$, $P=0.013)$. For the eight most abundant genera of forage forbs, only lupine (Lupinus L.) biomass decreased in phase III encroachment plots $(t=4.69, P=0.009)$; no other differences were significant for the individual genera of forage forbs $(P>0.05)$. There were no differences for forage availability between the paired reference plots and phase I or II encroachment $(P>0.05)$.

\section{Spring Prescribed Burning}

Terrestrial visibility and concealment measured at broader scales demonstrated relationships with the passage of time since the 10 spring prescribed burning treatments. There were decreases in terrestrial visibility measured at $8 \mathrm{~m}$ and $12 \mathrm{~m}$ over time in the burn treatment plots (8-m estimated slope $=-0.021 \pm 0.006 \mathrm{SE}$, $t=-3.56 ; P=0.024$, Fig. $1 \mathrm{~B} ; 12-\mathrm{m} \quad$ estimated slope $=-0.017 \pm 0.005 \mathrm{SE}, t=-3.64, P=0.028 ; \mathrm{df}=4, \alpha=0.05$ for results unless otherwise noted). Similarly, terrestrial concealment at $8 \mathrm{~m}$ and $12 \mathrm{~m}$ increased in burned areas over time $(8-\mathrm{m}$ estimated slope $=0.025 \pm 0.007 \mathrm{SE}, t=3.33, P=0.029$, Fig. $1 \mathrm{C}$; 12 -m estimated slope $=0.019 \pm 0.006 \mathrm{SE}, t=3.17, P=0.034)$. In contrast, there was not a significant trend over time for aerial concealment or terrestrial concealment or visibility measured at $4 \mathrm{~m}(P>0.05)$.

The passage of time since spring prescribed burning also affected potential forage for pygmy rabbits. As expected, mountain big sagebrush cover increased over time (estimated slope $=0.027 \pm 0.006 \mathrm{SE}, t=4.80, P=0.008$, Fig. 1D). Biomass of forage grasses decreased (estimated slope $=-0.052 \pm 0.018$ SE, $t=-2.92, P=0.043)$, but biomass of forage forbs did not exhibit a trend related to the passage of time since the burning treatment as sagebrush reestablishment occurred $(P=0.470)$. Similarly, we did not detect a significant response over time in the biomass of the eight most abundant forage forbs $(P>0.09)$.

We estimated the mean recovery times for habitat parameters (i.e., the average time after a burn when specific habitat characteristics did not differ from estimates in the reference plots) and associated $95 \%$ confidence intervals. Visibility and concealment from $8 \mathrm{~m}$ and $12 \mathrm{~m}$ had similar estimated recovery intervals (14-32 yr and 14-35 yr, respectively) after the burn treatment (Fig. 2). There was not a significant relationship between the passage of time after a burn and aerial concealment or terrestrial visibility and concealment measured at $4 \mathrm{~m}$. Therefore, the associated estimates for recovery were imprecise and ranged from $<10 \mathrm{yr}$ to as much as $70 \mathrm{yr}$ after the burn treatment. Our model predicted that sagebrush cover in burned areas would be equivalent to paired reference plots in $15 \mathrm{yr}$ to $30 \mathrm{yr}$ and grass biomass would be equivalent in $11 \mathrm{yr}$ to $30 \mathrm{yr}$ (Fig. 2). In contrast, biomass of forage forbs, either cumulatively or individually as the eight most abundant genera, were not significantly related to time since the burn, and consequently, the confidence interval for recovery was not informative $(<0 \mathrm{yr}$ to $400 \mathrm{yr})$. The average recovery interval across all significant habitat functional components was $13 \mathrm{yr}$ to $27 \mathrm{yr}$.

\section{Effect of Abiotic Factors}

Using the NMS to assess qualitatively whether community composition was related to plot type (burn, reference, phases IIII) or other abiotic factors (soil texture, aspect, study site), the only pattern in community composition was associated with plot type. Results of the ordination indicated that the appropriate dimensionality for the most parsimonious solution was two dimensions. The final ordination had a final stress value of 8.47 after 50 iterations, allowing for inference to be drawn. The reference plots and older fires clustered together tightly, with the younger burn plots scattered on the periphery of that cluster (Fig. 3A). The NMS ordination also demonstrated a gradual divergence of the conifer plots from the reference and burn plots with increasing phases of conifer encroachment (Fig. 3A). The other abiotic factors-soil texture (Fig. 3B), aspect (Fig. 3C), and the 10 study sites within which plots were nested (Fig. 3D)-evidenced a high level of the overlap of the convex hulls outlining each factor. The NMS ordination indicated connections between vegetation composition and disturbance-based plot types, but did not indicate associations with aspect, soil texture, or site-specific factors.

\section{DISCUSSION}

Phase III conifer encroachment and recent spring prescribed burns markedly altered habitat resources available to pygmy 

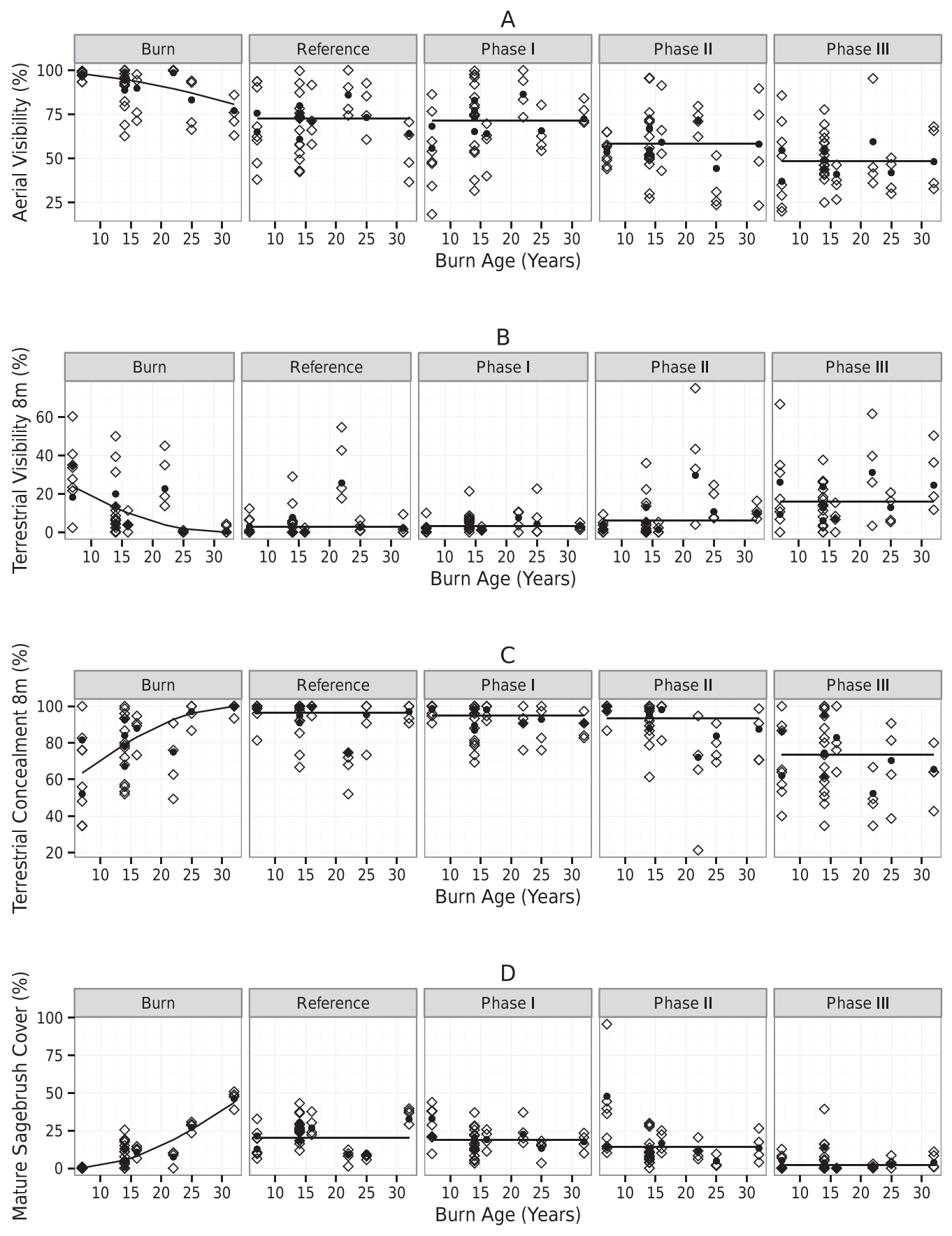

Figure 1. Estimates of $\mathbf{A}$, aerial visibility (\%), B, terrestrial visibility (\%) at $8 \mathrm{~m}, \mathbf{C}$, terrestrial concealment (\%) at $8 \mathrm{~m}$, and $\mathbf{D}$, mature mountain big sagebrush cover (\%) for burn, reference, and phase I-III encroachment plots at 10 sites treated with spring prescribed burns 6-32 yr ago in southwestern Montana and Idaho. The black dots indicate the model estimates for each plot. The hollow dots indicate the estimates for each transect (four transects per plot). The model estimates have been back-transformed and projected onto the original scale on the $y$-axis. The $x$-axis is the number of years since the burns were conducted, and therefore is a factor for the burn plots, but does not enter the models for the four other plots.

rabbits in the mountain big sagebrush steppe. Both disturbances affected cover components related to predation risk similarly; phase III encroachment and spring prescribed burns both decreased concealment and increased terrestrial visibility for small animals such as pygmy rabbits. Although an increase in visibility of the surrounding area might be beneficial in terms of the early detection of predators, this benefit could be negated by the magnitude of the decrease in concealment. Pygmy rabbits appear to use both concealment and visibility to manage their predation risk (Camp et al. 2013, 2013; Woods 2012); therefore, a marked increase in availability of one functional component of cover at the expense of another is likely to increase perceptions of risk for this species.

As with cover resources, both conifer encroachment and prescribed fires altered potential forage available to pygmy rabbits. Sagebrush, the primary forage for pygmy rabbits, significantly decreased with heavy encroachment (phase III encroached plots) and recent spring prescribed burns. Cover of 


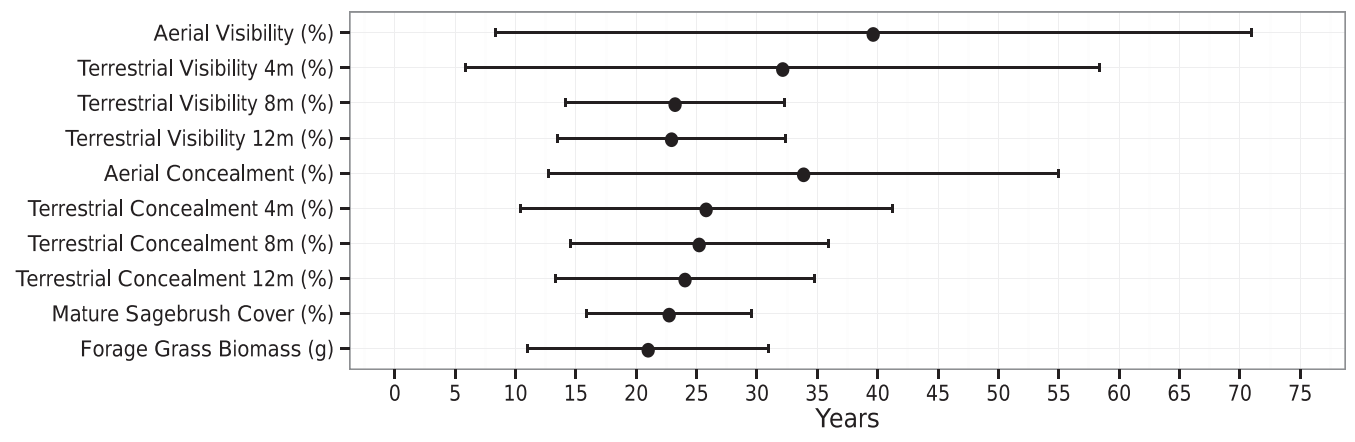

Figure 2. Means and associated 95\% confidence intervals for the years (on the x-axis) to recovery for sagebrush steppe habitat components for pygmy rabbits (on the $y$-axis) after spring prescribed burns in southwestern Montana and eastern Idaho. Variables with uninformative $<0$-yr confidence intervals are not pictured.

mature mountain big sagebrush demonstrated an exponential, nonlinear increase with time after a prescribed fire. A similar trend was documented in a previous study conducted in the same area (Lesica et al. 2007) and could be related, both individually or in combination, to increases in biomass accumulation as plants mature, availability of seed sources after maturation of the initial cohort, and suitable microhabitats for seed germination, although weather patterns can also have a strong effect on sagebrush recruitment (Lesica et al. 2007, Ziegenhagen and Miller 2009). Areas dominated by mountain big sagebrush can be more resilient to disturbance than other sagebrush subspecies, possibly because of greater seed viability, younger age to reproductive maturity, higher levels of precipitation, and greater resistance to invasion, but recovery intervals are still long compared to fire-adapted plant communities such as chaparral or tallgrass prairies (Bunting et al. 1987; Borchert and Odion 1995; Copeland et al. 2002; Knick et al. 2003; Lesica et al. 2007; Miller et al. 2013).

Responses of forage grasses and forbs differed between the two types of disturbance, conifer encroachment and spring prescribed burns. Phase III conifer encroachment significantly decreased both forage grass and forb biomass. The response of forbs and grasses to spring prescribed burning was variable. Our burn plots exhibited an increase in grass production early in the recovery of a burn $(<14 \mathrm{yr})$ followed by a slow decrease over time, but there was no significant trend for biomass of forbs. It is important to note, however, that our most recent fire occurred $6 \mathrm{yr}$ ago, and there could be significant changes in the initial $5 \mathrm{yr}$ following a fire that we were unable to quantify with our sample. Studies conducted within both Wyoming big sagebrush and mountain big sagebrush communities have documented short-term increases in grasses and annual forbs after burning, but short-duration responses by perennial forbs are more unusual (Harness and Murray 1973; Wambolt et al. 2001; Bates et al. 2009; Rhodes et al. 2010; Davies et al. 2012; but see Bates et al. 2011). Typically, fire increases nutrient cycling and could promote short-term increases in grass and forb production in sagebrush steppe, but it is less likely to provide long-term enhancement, and effects could vary markedly across sites, years, and individual species (Bunting et al. 1987; Wambolt and Sherwood 1999; Beck et al. 2009; Beck et al. 2011; Miller et al. 2013).

Substitution of space for time in study designs like ours introduces potentially confounding site-level factors that could influence interpretation of the effect of changes in measured characteristics over time. To evaluate this potential, we visualized community composition across our plots, as described by the NMS ordination, with the expectation that plots should be grouped according to the treatment, but not other environmental factors. Our results followed this expected pattern and appeared to reflect the influence of the disturbance on community composition.

One important concern about use of prescribed burning in sagebrush habitats is the potential for spread of invasive species following fires (Davies et al. 2011). We documented little occurrence of invasive species within the study sites. This is not unusual because the establishment of invasive plants in mountain big sagebrush typically is limited by cold temperatures and short growing seasons (Chambers et al. 2007; Davies et al. 2011; Miller et al. 2013). However, cheatgrass was present (although not dominant) at one prescribed burn site with a southern aspect and steep slope. These topographic characteristics might have produced a warmer microclimate similar to lower elevations where cheatgrass invasion is more likely to occur (Chambers et al. 2007). Generalizations about the potential for invasive plant establishment, based on vegetation types associated with sagebrush subspecies, might not always reflect site-specific conditions.

In the sagebrush steppe, fire is a process that shapes future vegetation communities and wildlife habitat (Young and Evans 1978). Our models estimated that $13 \mathrm{yr}$ to $27 \mathrm{yr}$ were required for spring prescribed burns to provide cover and forage resources similar to unburned sagebrush steppe reference plots. This result is similar to previously estimated recovery times of $15 \mathrm{yr}$ to $20 \mathrm{yr}$ postburn (Bunting et al. 1987), although slightly shorter than other estimated intervals of $30 \mathrm{yr}$ to $40 \mathrm{yr}$ for recovery (Harniss and Murray 1973; Lesica et al. 2007; Wambolt et al. 2001). However, individual functional habitat components did differ in their estimated means and confidence intervals for the return to reference plot conditions. Forage grasses provided an earlier, but more variable, estimated recovery interval compared to mountain big sagebrush, whereas forage forbs, collectively and individually, were too variable to allow for any inference. Cover components related to predation risk (visibility and concealment) from aerial and close terrestrial (4-m) perspectives had earlier, but more variable, recovery intervals compared with terrestrial measurements taken at broader scales $(8 \mathrm{~m}$ and $12 \mathrm{~m})$. Therefore, all 


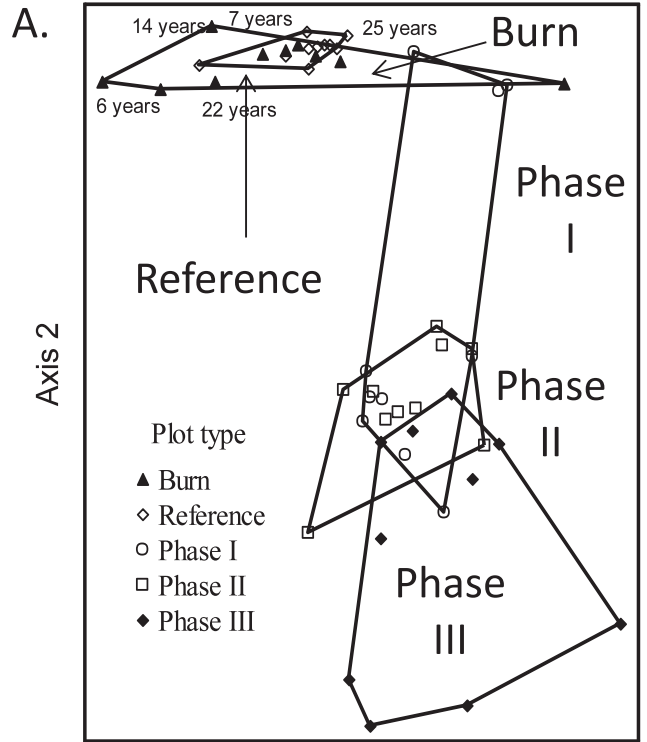

Axis 1

C.

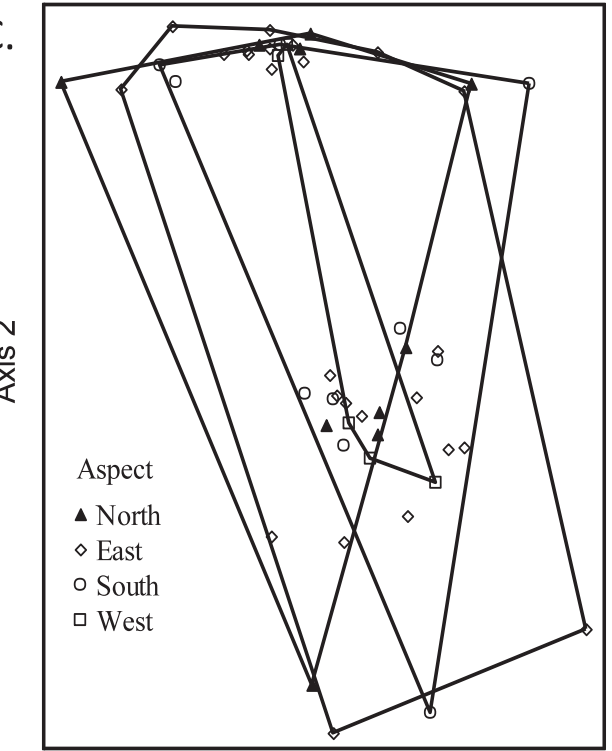

Axis 1

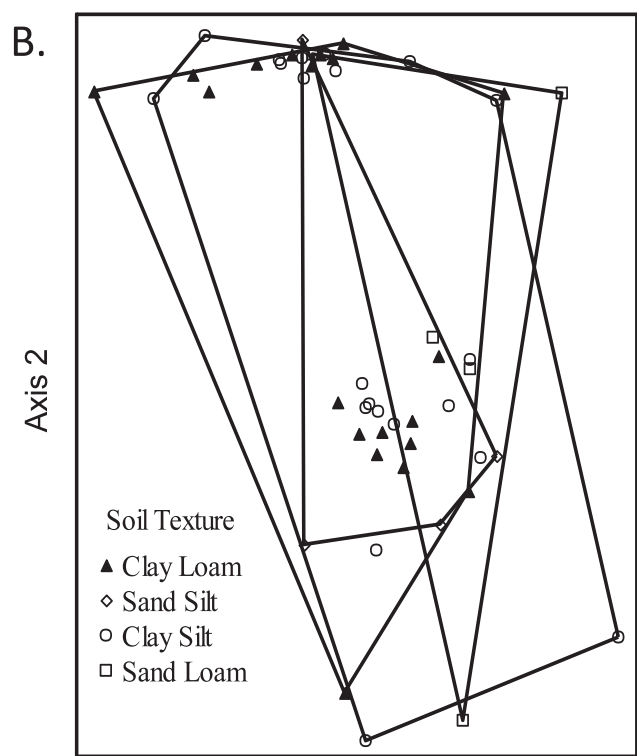

Axis 1

D.

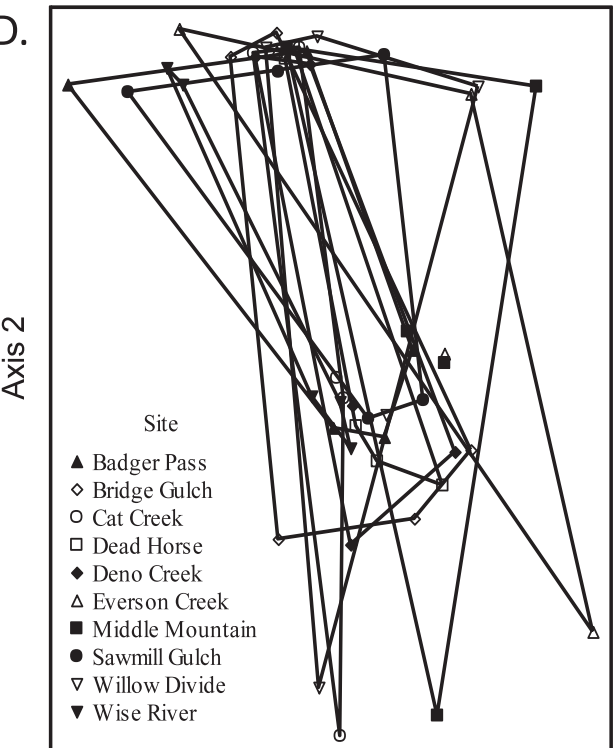

Axis 1

Figure 3. The nonmetric multidimensional scaling ordination for vegetation community composition grouped by $\mathbf{A}$, plot type (burn, reference, phases I-III), B, soil texture, C, aspect, and D, study site for 10 sagebrush sites in southwestern Montana and eastern Idaho. Axes 1 and 2 represent similarities among plots, whereas the convex hulls connect plots of the same study site. The high level of overlap in the hulls indicates that study site characteristics do not have a strong relationship to community composition.

aspects of habitat might not recover simultaneously, potentially creating a disconnect between the vegetation characteristics and resources they provide to wildlife.

\section{IMPLICATIONS}

The loss of functional components of the habitat for wildlife in areas of conifer encroachment and spring prescribed burning creates a conundrum for managers. If left unchecked over several decades, conifer encroachment will effectively eliminate sagebrush habitat. The magnitude of disturbance required to remove well-established conifers and the lack of remaining sagebrush seed sources can limit the likelihood of sagebrush reestablishing in the future (Davies et al. 2011). If spring burning is used to curtail conifer encroachment, burned areas will eventually return to sagebrush vegetation, but the changes created by fire are rapid, and up to three decades could be required for all habitat functions to recover to an unburned state. If management goals include maintaining sagebrush habitats and wildlife, such as pygmy rabbits, managers could consider the following questions: Is conifer encroachment occurring and are control measures necessary to maintain 
sagebrush habitat for the future? If control of encroachment is necessary, are pygmy rabbits present within the treatment area? If so, is there adjacent habitat that could support pygmy rabbit populations during the recovery interval?

Loss of sagebrush in burned areas will make stands treated with prescribed fire unsuitable for pygmy rabbits, and a recent study suggests that edges of treated stands are avoided by this species (Wilson et al. 2011). Therefore, in addition to considering differing techniques for control of encroaching conifers (prescribed burning, mechanical treatment, herbicide), the size, timing, and spatial arrangement of treatments should be important points of consideration for managers in areas where sagebrush-specialist wildlife species occur. Additionally, responses to spring burning in mountain big sagebrush should not be extrapolated to other sagebrush communities and fire regimes. The use of prescribed fire in areas that do not require the control of conifers or are at risk from cheatgrass invasion would be counterproductive to conserving sagebrush-associated wildlife. Understanding the effects of disturbance and developing management tools that allow for regeneration and long-term continuance of sagebrush steppe is important for conserving the wildlife species that rely on sagebrush steppe ecosystems.

\section{ACKNOWLEDGMENTS}

We greatly appreciate the support of M. Steck, R. Martin, K. Schmidt, A. Shovlain, P. Makela, B. Waterbury, V. Guyer, B. Davitt, the Rachlow Lab group, K. Reese, C. Wambolt, J. Stafford, C. E. Tuss, E. Wyatt, K. Blotkamp, I. Drieling, the Stanfield family, and K. Holloway, who all helped to make this project possible. Two anonymous reviewers provided comments that improved the manuscript.

\section{LITERATURE CITED}

Allen, E. A., J. C. Chambers, and R. S. Nowak. 2008. Effects of a spring prescribed burn on the soil seed bank in sagebrush steppe exhibiting pinyon-juniper expansion. Western North American Naturalist 68:265-277.

Arno, S. F., and G. E. Gruell. 1983. Fire history at the forest-grassland ecotone in southwestern Montana. Journal of Rangeland Management 36:332-336.

Bates, J. D., K. W. Davies, and R. N. Sharp. 2011. Shrub-steppe early succession following invasive juniper cutting and prescribed fire. Environmental Management 47:468-481.

Bates, J. D., R. F. Miller, and K. W. Davies. 2006. Restoration of quaking aspen woodlands invaded by western juniper. Rangeland Ecology \& Management 59:88-97.

Bates, J. D., E. C. Rhodes, K. W. Davies, and R. Sharp. 2009. Postfire succession in big sagebrush steppe with livestock grazing. Rangeland Ecology \& Management 62:98-110.

Beck, J. L., J. W. Connelly, and K. P. Reese. 2009. Recovery of greater sage-grouse habitat features in Wyoming big sagebrush following prescribed fire. Restoration Ecology 17:393-403.

Beck, J. L., J. G. KLein, J. Wright, And K. P. Wolfley. 2011. Potential and pitfalls of prescribed burning big sagebrush habitat to enhance nesting and early broodrearing habitats for greater sage-grouse. Natural Resources and Environmental Issues 16:27-32.

BEYER, H. L. 2004. Hawth's analysis tools for ARCGIS. Available at: http://www. spatialecology.com/htools. Accessed 12 April 2011.

Borchert, M. L., AND D. C. Odion. 1995. Fire intensity and vegetation recovery in chaparral: a review. In: J. E. Keeley and T. Scott [EDS.]. Brushfires in California wildlands: ecology and resource management. Fairfield, WA, USA: International Association of Wildland Fire. p. 91-100.

Brooks, M. I., C. M. D’Antonio, D. M. Richardson, J. B. Grace, J. E. Keeley, J. M. Ditomaso, R. J. Hobbs, M. Pellant, and D. Pyke. 2004. Effects of invasive alien plants on fire regimes. BioScience 54:677-688.

Bunting, S. C., B. M. Kilgore, AND C. L. Bushey. 1987. Guidelines for prescribed burning sagebrush-grass rangelands in the northern Great Basin. Ogden, UT, USA: USDA Forest Service Intermountain Research Station. General Technical Report INT231. $33 \mathrm{p}$.

Burkhardt, J. W., AND E. W. Tisdale. 1976. Causes of juniper invasion in southwestern Idaho. Ecology 57:472-484.

Camp, M. J., J. L. Rachlow, B. A. Woods, T. R. Johnson, and L. A. Shipley. 2012. When to run and when to hide: the influence of concealment, visibility, and proximity to refugia on perceptions of risk. Ethology 118:1010-1017.

Camp, M. J., J. L. Rachlow, B. A. Woods, T. R. Johnson, and L. A. Shipley. 2013. Examining the functional components of cover: the relationship between concealment and visibility in shrub-steppe habitat. Ecosphere 4:art19 doi:10.1890/ES12-00114.1.

Canfield, R. H. 1941. Application of the line interception method in sampling range vegetation. Journal of Forestry 39:388-394.

Chambers, J. C., B. A. Roundy, R. R. Blank, S. E. Meyer, and A. Whittaker. 2007. What makes Great Basin sagebrush ecosystems invasible by Bromus tectorum? Ecological Monographs 77:117-145.

CLARKE, K. R. 1993. Non-parametric multivariate analyses of changes in community structure. Australian Journal of Ecology 18:117-143.

Commons, M. L., R. K. Baydack, and C. E. Braun. 1999. Sage-grouse response to pinyon-juniper management. In: S. Monson and R. Stevens [EDS.]. Proceedings: Ecology and management of pinyon-juniper communities within the interior west. Fort Collins, C0, USA: USDA Forest Service. RMRS-P-9. p. 238-239.

Copeland, T. E., W. Sluis, and H. F. Howe. 2002. Fire season and dominance in Illinois tall grass prairie restoration. Restoration Ecology 10:315-323.

Crawford, J. A., R. G. Anthony, J. T. Forbes, and G. A. Lorton. 2010. Survival and causes of mortality for pygmy rabbits (Brachylagus idahoensis) in Oregon and Nevada. Journal of Mammalogy 91:838-847.

Davies, K. W., J. D. Bates, and A. M. Nafus. 2012. Comparing burned and mowed treatments in mountain big sagebrush steppe. Environmental Management 50:451-461.

Davies, K. W., C. S. Boyd, J. L. Beck, J. D. Bates, T. J. Svejcar, and M. A. Gregg. 2011. Saving the sagebrush sea: an ecosystem conservation plan for big sagebrush plant communities. Biological Conservation 144:2573-2584.

DavitT, B. B., AND J. R. Nelson. 1980. A method to prepare plant epidermal tissue for use in fecal analysis. Pullman, WA, USA: Washington State University, College of Agriculture Research Center. Circ. 0628:1-4.

Embar, K., B. P. Kotler, and S. Mukherjee. 2011. Risk management in optimal foragers: the effect of sightlines and predator type on patch use, time allocation, and vigilance in gerbils. Oikos 120:1657-1666.

ESRI [COMPUTER PROGRAm]. 2011. ArcGIS desktop: release 10. Redlands, CA, USA: ESRI.

Estes-Zumpf, W. A., And J. L. Rachlow. 2009. Natal dispersal by pygmy rabbits (Brachylagus idahoensis). Journal of Mammalogy 90:363-372.

Faith, D. P., P. R. Minchin, And L. Belbin. 1987. Compositional dissimilarity as a robust measure of ecological distance. Plant Ecology 69:57-68.

Gabler, K. I., L. T. Heady, and J. W. Laundré. 2001. A habitat suitability model for pygmy rabbits (Brachylagus idahoensis) in southeastern Idaho. Western North American Naturalist 61:480-489.

GaHR, M. L. 1993. Natural history, burrow habitat and use and home range of the pygmy rabbits (Brachylagus idahoensis) of Sagebrush Flat, Washington [thesis]. Seattle, WA, USA: University of Washington. $126 \mathrm{p}$.

Green, J. S., AND J. T. Flinders. 1980. Habitat and dietary relationships of the pygmy rabbit in southeastern Idaho vegetation. Journal of Range Management 33:136142.

Harniss, R. O., And R. B. MurRay. 1973. 30 years of vegetal change following burning of sagebrush-grass range. Journal of Range Management 26:322-325.

Haugo, R. D., and C. B. Halpern. 2007. Vegetation responses to conifer encroachment in a western Cascade meadow: a chronosequence approach. Canadian Journal of Botany 85:285-298. 
Houston, D. B. 1973. Wildfires in northern Yellowstone National Park. Ecology 54:1111-1117.

Johnson, J. R., And G. F. Payne. 1968. Sagebrush reinvasion as affected by some environmental influences. Journal of Range Management 21:209-213.

KNaPP, P. A., AND P. T. Soulé. 1996. Vegetation change and the role of atmospheric $\mathrm{CO}_{2}$ enrichment on a relict site in central Oregon: 1960-1994. Annals of the Association of American Geographers 86:387-411.

KnapP, P. A., AND P. T. SoulÉ. 2008. Use of atmospheric $\mathrm{CO}_{2}$-senstive trees may influence dendroclimatic reconstructions. Geophysical Research Letters 35:1-5.

Knick, S. T., D. S. Dobkin, J. T. Rotenberry, M. A. Schroeder, W. M. Vander Haegen, and C. VAN RIPER III. 2003. Teetering on the edge or too late? Conservation and research issues for avifauna of sagebrush habitats. The Condor 105:611-634.

Knick, S. T., A. L. Holmes, and R. F. Miller. 2005. The role of fire in structuring sagebrush habitats and bird communities. Studies in Avian Biology 30:1-13.

KRUSKAL, J. B. 1964. Multidimensional scaling by optimizing goodness of fit to a nonmetric hypothesis. Psychometrika 29:1-27.

Lesica, P., S. V. Cooper, and G. Kudray. 2007. Recovery of big sagebrush following fire in southwest Montana. Rangeland Ecology \& Management 60:261-269.

LIMA, S. L., AND L. M. DiLL. 1990. Behavioral decisions made under the risk of predation: a review and prospectus. Canadian Journal of Zoology 68:619-640.

McCune, B., And M. J. MefFord. 2011. PC-ORD. Multivariate analysis of ecological data. Version 6. Gleneden Beach, OR, USA: MjM Software.

Miller, R. F., J. D. Bates, T. J. Svejcar, F. B. Pierson, and L. E. Eddleman. 2005. Biology, ecology and management of western juniper. Corvallis, OR, USA: Oregon State University, Agricultural Experiment Station. Technical Bulletin 152. $82 \mathrm{p}$.

Miller, R. F., J. C. Chambers, D. A. Pyke, F. B. Pierson, and C. J. Willams. 2013. Fire effects on vegetation and soils in the Great Basin region: response and site characteristics. Boise ID, USA: USDA Forest Service Rocky Mountain Research Station. Research Paper RMRS-RP-(in press). $125 \mathrm{p}$.

Miller, R. F., L. Eddleman, and Oregon State University Agricultural Experiment Station. 2000. Spatial and temporal changes of sage-grouse habitat in the sagebrush biome. Corvallis, OR, USA: Oregon State University, Agricultural Experiment Station. Technical Bulletin 151. $35 \mathrm{p}$.

Miller, R. F., And J. A. Rose. 1999. Fire history and western juniper encroachment in sagebrush steppe. Journal of Range Management 52:550-559.

MILleR, R. F. AND R. J. TAUSCH. 2001. The role of fire in pinyon and juniper woodlands: a descriptive analysis. In: K. E. M. Galley and T. P. Wilson [EDS.]. Proceedings of the Invasive Species Workshop: The Role of Fire in the Control and Spread of Invasive Species. Fire Conference 2000: The First National Congress on Fire Ecology, Prevention, and Management; 27 November-1 December 2000; San Diego, CA, USA. Tallahassee, FL, USA: Tall Timbers Research Station. Miscellaneous Publication No. 11. p. 15-30.

[NOAA] National Oceanic and Atmospheric Administration. 2012. 30 year normals from Butte Montana. Available at: http://www.wrh.noaa.gov/mso/climate/norm 30y. html. Accessed 13 February 2012.

Noss, R. F., E. T. LARoE, AND J. M. Scott. 1995. Endangered ecosystems of the United States: a preliminary assessment of loss and degradation. Washington, D.C., USA: US Department of the Interior, National Biological Service. Biological Report 28. p. 58.

PeCK, J. E. 2010. Multivariate analysis for community ecologists: step-by-step using PC-ORD. Gleneden Beach, OR, USA: MjM Software Design. 162 p.

Price, A. J., W. Estes-ZumpF, and J. RACHLow. 2010. Survival of juvenile pygmy rabbits. The Journal of Wildlife Management 74:43-47.

Rhodes, E. C., J. D. Bates, K. W. Davies, and R. N. Sharp. 2010. Fire effects on cover and dietary resources of sage-grouse habitat. Journal of Wildlife Management 74:755-764.

Sanchez, D. M., AND J. L. RaCHLow. 2008. Spatio-temporal factors shaping diurnal space use by pygmy rabbits. The Journal of Wildlife Management 72:13041310.
SAS Institute. 2008. SAS software. Version 9.2. Cary, NC, USA: SAS Institute, Inc. Schroeder, M. A., C. L. Aldridge, A. D. Apa, J. R. Bohne, C. E. Braun, S. D. Bunnell, J. W. Connelly, P. A. Deibert, S. C. Gardner, M. A. Hilliard, G. D. Kobriger, S. M. McAdam, C.W. McCarthy, J. J. McCarthy, D. L. Mitchell, E. V. Rickerson, and S. J. Stiver. 2004. Distribution of sage-grouse in North America. The Condor 106:363-376.

SIDAK, Z. 1967. Rectangular confidence regions for the means of multivariate normal distributions. Journal of the American Statistical Association 62:626-633.

SIEGEL, N. J. 2002. Ecology of pygmy rabbits at Sagebrush Flat in central Washington [thesis]. Pullman, WA, USA: Washington State University. $73 p$.

Suring, L. H., M. J. Wisdom, R. J. Tausch, R. F. Miller, M. M. Rowland, L. Schueck, and C. W. MeINKE. 2005. Modeling threats to sagebrush and other shrubland communities. In: M. J. Wisdom, M. M. Rowland, and L. H. Suring [EDS.]. Habitat threats in the sagebrush ecosystem: methods of regional assessment and applications in the Great Basin. Lawrence, KS, USA: Alliance Communications Group. p. 114-149.

TAUSCH, R. J. 1999. Transitions and thresholds: influences and implications for management in pinyon and Utah juniper woodlands. In: S. B. Monsen, R. Stevens, R. J. Tausch, R. Miller, and S. Goodrich [EDS.]. Proceedings: ecology and management of pinyon-juniper communities within the Interior West. Ogden, UT, USA: USDA Forest Service Rocky Mountain Research Station. Proceedings RMRS-P-9. p. 61-65.

Thien, S. J. 1979. A flow diagram for teaching texture by feel analysis. Journal of Agronomic Education 8:54.

Thines, N. J., L. A. Shipley, And R. D. SAYler. 2004. Effects of cattle grazing on ecology and habitat of Columbia Basin pygmy rabbits (Brachylagus idahoensis). Biological Conservation 119:525-534.

USDA-NRCS. 2011. Web soil survey. Available at: http://websoilsurvey.nrcs.usda. gov. Accessed 10 April 2011.

WamBolt, C. L., AND H. W. SherWOod. 1999. Sagebrush response to ungulate browsing in Yellowstone. Journal of Range Management 52:363-369.

Wambolt, C. L., K. S. Walhof, and M. R. Frisina. 2001. Recovery of big sagebrush communities after burning in south-western Montana. Journal of Environmental Management 61:243-252.

WEST, N. E. 1996. Strategies for maintenance of and repair of biotic community diversity on range-lands. In: R. C. Szaro and D. W. Johnston [EDS.]. Biodiversity in managed landscapes: theory and practice. New York, NY, USA: Oxford University Press. p. 342-346.

WEST, N. E. 2000. Synecology and disturbance regimes of sagebrush steppe ecosystems. In: P. G. Entwistle, A. M. DeBolt, J. H. Kaltenecker, and K. Steenhof [EDS.]. Proceedings: Sagebrush Steppe Ecosystems Symposium; 21-23 June 1999; Boise, ID, USA. Boise, ID, USA: US Department of Interior, Bureau of Land Management. Publication No. BLM/ID/PT-001001+1150. p. 15-26.

Wilson, T. L., F. P. Howe, AND T. C. Edwards. 2011. Effects of sagebrush treatments on multi-scale resource selection by pygmy rabbits. The Journal of Wildlife Management 75:393-398.

Winfree, R., T. Griswold, and C. Kremen. 2007. Effects of human disturbance on bee communities in a forested ecosystems. Conservation Biology 21:213-223.

Winward, A. H. 1985. Fire in the sagebrush-grass ecosystems; the ecological setting. In: K. Sanders and J. Durham [EDS.]. Rangeland Fire Effects: A Symposium; 2729 November 1984; Boise, ID, USA. Boise, ID, USA: US Department of Interior, Bureau of Land Management. p. 2-6.

Woods, B. A. 2012. The pygmy rabbit: predation risk, habitat structure and fire dynamics in sagebrush steppe [thesis]. Moscow, ID, USA: University of Idaho. $111 \mathrm{p}$.

Young, J. A., And R. A. Evans. 1978. Population dynamics after wildfires in sagebrush grasslands. Journal of Range Management 31:283-289.

Ziegenhagen, L. L., and R. F. Miller. 2009. Postfire recovery of two shrubs in the interiors of large burns in the Intermountain West. Western North American Naturalist 69:195-205. 